\title{
DESIGNING ANDROID BASED GAME TO EDUCATE THE CENTRAL JAVA TRADITIONAL MUSIC INSTRUMENT FOR CHILDREN
}

\author{
Helarius Panji Aruna ${ }^{1}$, Albertus Dwiyoga $\mathrm{W}^{2}$, Bernardinus Harnadi ${ }^{3}$ \\ Game Technology Program, Information System Department \\ Soegijapranata Catholic University \\ 141n20004@student.unika.ac.id, 2yoga@unika.ac.id, ${ }^{3}$ berdi@unika.ac.id
}

\begin{abstract}
This research was held to design \& create games that can provide children with knowledge of traditional musical instruments in Central Java.

The initial design of the game is done by collecting data by interviewing the speakers. The game was created using Construct 2 . This game has 5 different gameplay and when completing each stage you will get 3 traditional musical instruments except stage 5. Players can get information about traditional musical instruments and the sounds they produce. The game was tested on 41 respondents and the results of the game had a positive impact on players and provided new knowledge about traditional musical instruments.
\end{abstract}

Keywords: Traditional Music Instruments, Playing While Learning, Construct 2, Central Java Android Games

\section{INTRODUCTION}

In this era of globalization, young people prefer modern music than traditional music and rarely find traditional musical instruments. Music art lessons that use traditional musical instruments for children are also rarely found. Based on research, teachers felt that they did not have enough expertise to teach music art material so some teachers agreed that music art was omitted from the curriculum [1].

Some indigenous Indonesian cultures have been known abroad. For example batik, reog ponorogo, gamelan etc. There are even neighboring countries that claim that culture is their country's native culture. A typical Javanese musical instrument, gamelan has become an international conversation because the gamelan is claimed by other countries as its original culture [2]. This is caused by technological advancements that facilitate ways to imitate / adopt and attenuate boundaries between countries so that a cultural / copyright regulation belonging to a country protected by a world body that oversees culture in this case is UNESCO (Union of countries ) Education, Science and Culture Organization.

The younger generation does not respect and preserve traditional Javanese musical instruments because of the monotonous rhythm. The younger generation prefers to follow the flow of western culture and modernization. They assume that traditional music is not trendy and old-fashioned [3]. The decreasing interest of young people, especially in Java to see performances of Javanese art, is evidence of these things.

The flow of globalization that has resulted in the entry of foreign cultures is a strong attraction for the younger generation. This is also the reason why young people are less interested in traditional music. Though traditional music is a national cultural identity that must be considered by society, not just the government [4].

Many foreigners come to Indonesia to learn traditional music because traditional music abroad is more famous there than in their own country. They come to learn and then develop in their respective countries. If this is left unchecked then it is possible that our traditional music will be taken and lost [5].

It is important to preserve traditional music culture in Indonesia so that culture remains and is not lost due to globalization. Community care is also needed in the preservation of traditional music culture.

How to provide learning so as not to be monotonous and fun is done by making the 
game a learning medium. Primary students like to learn where they can play and learn. It is hoped that by using the game as a medium of learning about traditional musical instruments, students can care more and have a sense of belonging to their culture in their own country [6].

Learning about traditional musical instruments using games has the advantage that students pay more attention, are not bored with lessons, learning will be more alive, and more. Traditional musical instruments in the game that will be made by researchers are traditional musical instruments in Central Java, including Solo and Yogyakarta, which are peking, saron, demung, slenthem, kempul, gong, bonang, gambang, gender, rebab, siter, dan kendang (gamelan).

\section{METHOD}

The problem taken by researchers is cultural and social problems, and therefore researchers choose research methods that are qualitative and quantitative.

According to Nana Sudjana and Ibrahim (2001: 84), population is all data that has the opportunity to provide information that can be used by researchers [7]. The population in this study involved 41 students in elementary schools in the city of Semarang.

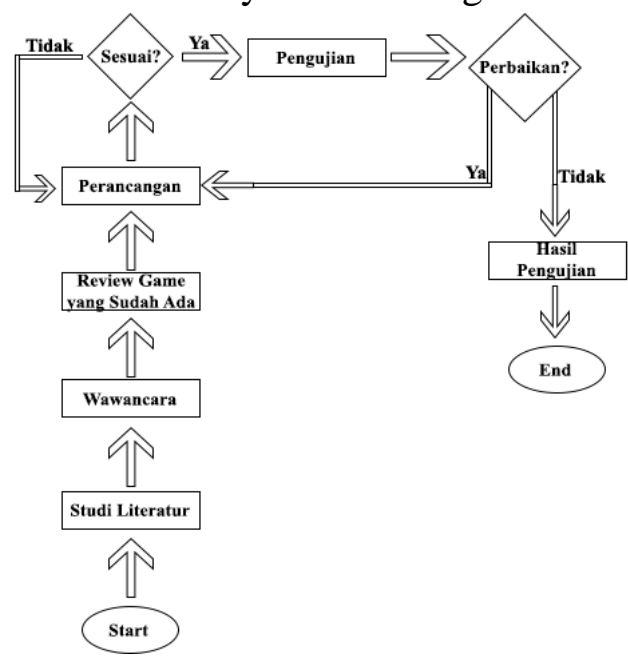

Figure 1 Research Flowchart

The research began with the study of literature. Followed by the interview stage to the resource person. After that the researchers conducted a review of several existing similar games. Then the researchers began designing the game using the data that had been collected. Then the researchers looked at and consulted the games that had been designed whether they were suitable or not to the mentor. If it is not right for the researcher to do the redesign, if appropriate the researcher conducts the test by distributing the questionnaire. After obtaining data from testing, the researcher processes the data. Then the information obtained from processing the data was made by the researcher as a reference whether or not to make improvements to the game. If repairs are needed, the researcher will correct the game and will retest, if there is no improvement, the game enters the finalization or outcome stage.

\section{RESULTS AND DISCUSSION}

The game "Joko Sinau: Traditional Music in Central Java" is the title of the game based on Android genre adventure. The process of making games from start to finish uses an engine / software called Construct 2.

Drawing, animation, and graphic design in this game uses Adobe Photoshop and Corel Draw x7 software.

\section{A. Flow on the Game "Joko Sinau:}

Traditional Music in Central Java"

The storyline found in the game "Joko Sinau: Traditional Music Ing Central Java" can be seen in Figure 2.

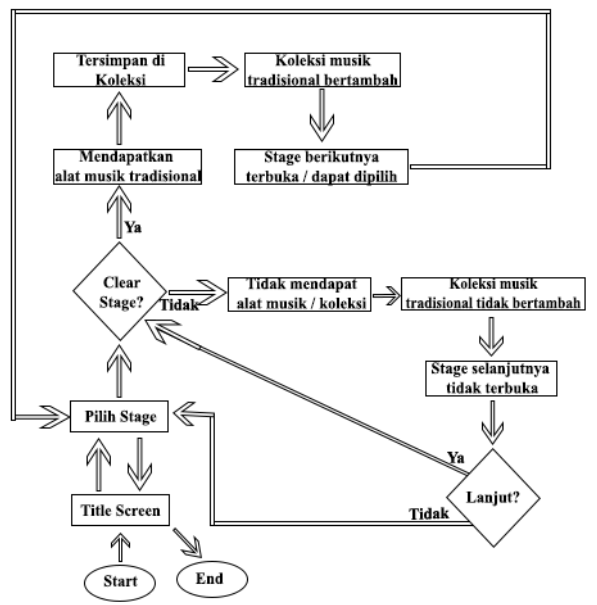

Figure 2 Game Story Flow

The game "Joko Sinau: Traditional Music in Central Java" starts with the start of the title screen / main menu pressing the play button. After pressing the play button, the player will be given the option to choose the 
available stage. At the beginning the player can only choose one stage. Players are required to complete each stage to access the next stage. The number of stages in this game is 5 .

The player succeeds in completing one stage if the player gets all the traditional musical instruments in the treasure chest and in the form of a fraction. Each stage has 3 traditional musical instruments except stage 5. All traditional musical instruments that have been obtained from each stage will be stored in the collection. The next stage will be automatically accessible.

The player will fail to complete the stage if the player cannot get all the traditional musical instruments in one stage. Players will also not get traditional musical instruments on the Collection page in the game. In addition, players also cannot continue to the next stage.

\section{B. Main Menu}

When the game starts, the initial display will appear, the main menu. On the main menu there are 5 buttons that have different functions accompanied by traditional background music from the typical Central Javanese gamelan. Display the main menu can be seen in Figures 3 and 4 .

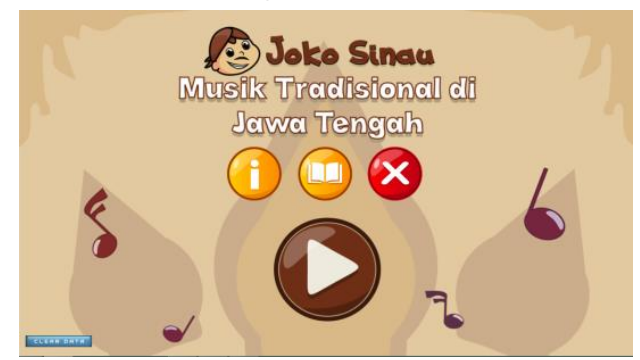

Figure 3 Main Menu

Figure 3 is the main menu in the game "Joko Sinau: Traditional Music in Central Java". There are play, information, collection and exit game buttons.

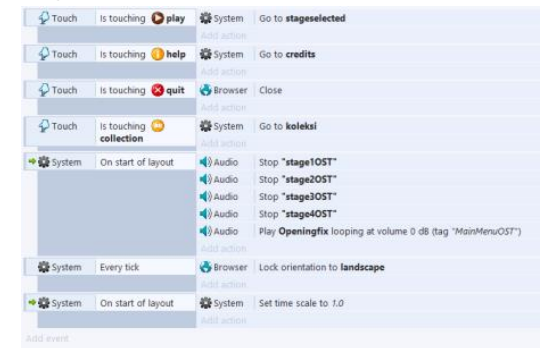

Figure 4 Main Menu Event Sheets
Figure 4 is event sheets for the main menu layout. There is a command so that the buttons on the main menu function and the background music also lights up properly.

\section{Stage Selection}

When a player presses the play button on the main menu, the player will be given a choice of stages. The stage selection display can be seen in Figures 5 and 6.

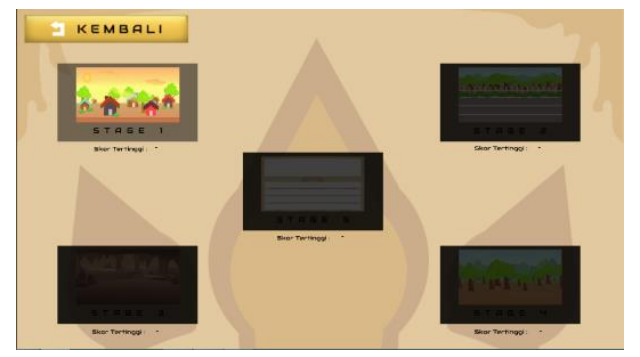

Figure 5 Stage Selection

At first the player can only play stage I but if the player can complete the stage then the next stage will be accessible. The button on the top left is the back button which will return the display to the main menu when pressed.

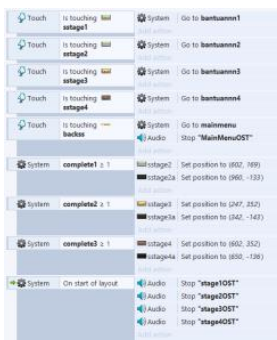

Figure 6 Stage Options Event Sheets

Figure 6 is an image of event sheets in the stage selection layout. There is a command or command to enable the stage image when pressed will go to that stage. Also to enable the back button and the command to control the music that appears.

\section{Help}

After the player chooses the stage in the stage selection, a layout will appear showing help for the selected stage. This help layout can also be accessed on the popup menu when the pause button is pressed. The views for the help layout for each stage are in Figures 7, 9, 11, 13 and 15. Display event sheets for help layouts are in Figures 8, 10, 12,14 and 16. 


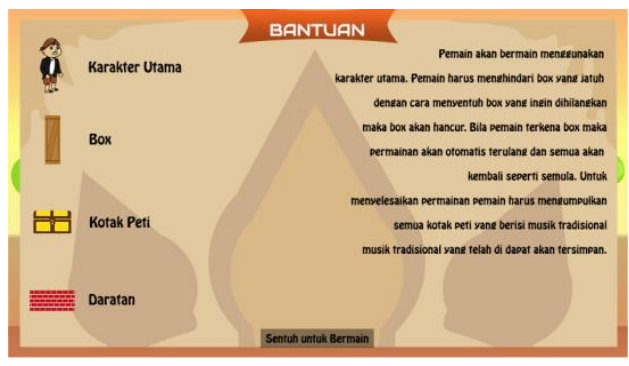

Figure 7 Stage I Help

Figure 7 is a layout for help for stage I. There is a brief explanation of what the player must do in the stage I and the names of the objects at that stage.

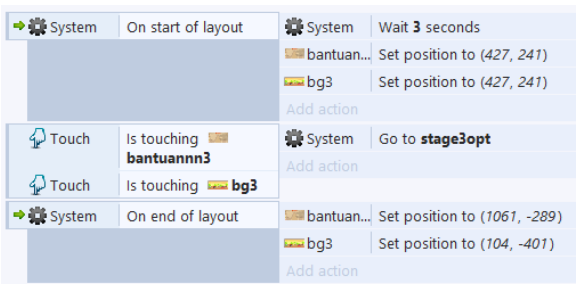

Figure 8 Stage I Help Event Sheets

Figure 8 is event sheets from the stage I help layout. There is a command / command to layout stage I. After the player waits for 3 seconds, the image in the layout can be clicked and the stage I game starts.

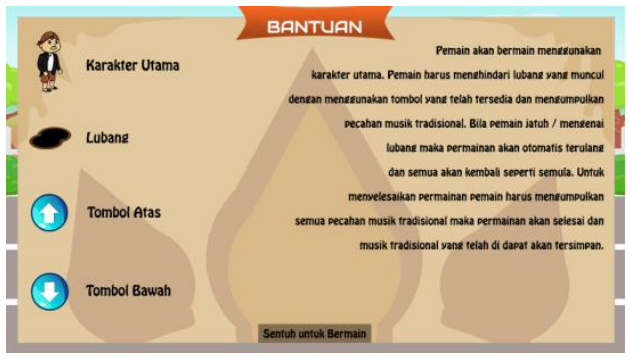

Figure 9 Stage II Help

Figure 9 is a layout for help for stage II. There is a brief explanation of what the player must do in stage II and the names of objects that are on the stage.

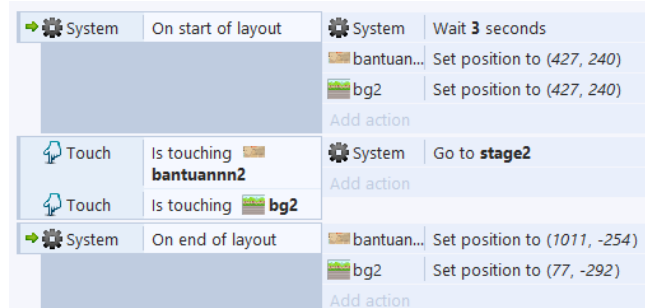

Figure 10 Stage II Help Event Sheets

Figure 10 is event sheets from stage II help layouts. There is a command to stage II. After the player waits for 3 seconds, the image in the layout can be clicked on and the stage II game starts.

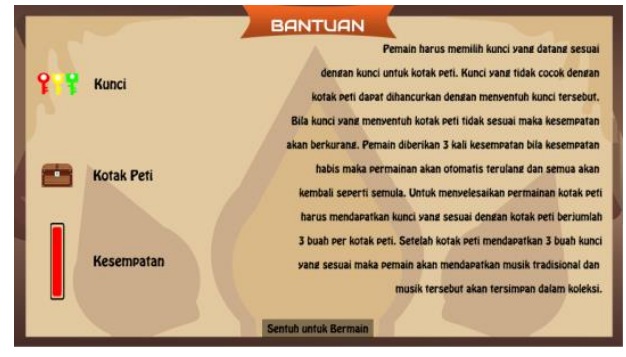

Figure 11 Stage III Help

Figure 11 is a layout for help for stage III. There is a brief explanation of what the player must do in stage III and the names of objects that are on the stage.

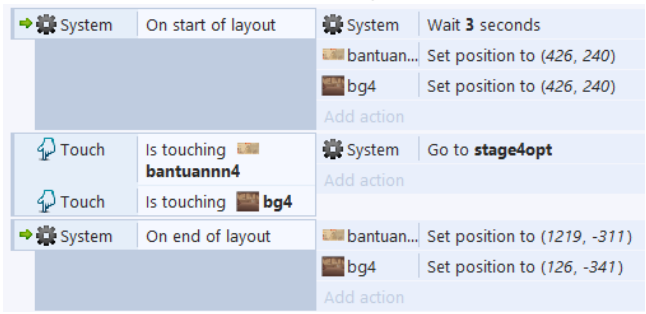

Figure 12 Stage III Help Event Sheets

Figure 12 is event sheets from the stage III help layout. There is a command for the stage III layout. After the player waits for 3 seconds, the image in the layout can be clicked on and the stage III game starts.

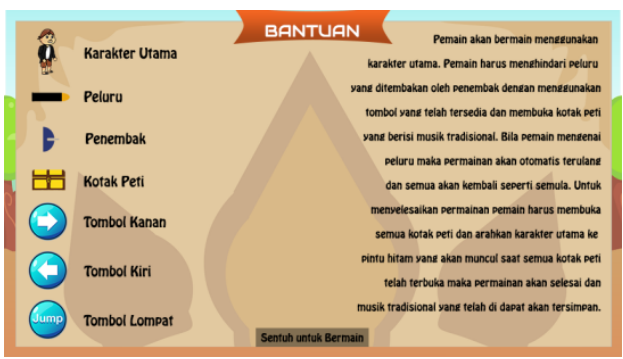

Figure 13 Stage IV Help

Figure 13 is a layout for help for stage IV. There is a brief explanation of what the player must do in stage IV and the names of objects that are on the stage.

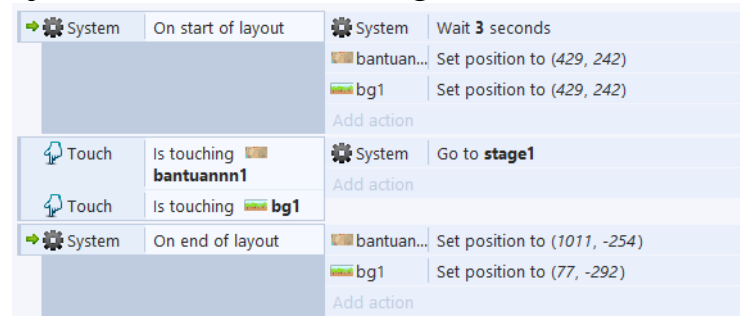

Figure 14 Stage IV Help Event Sheets

Figure 14 is event sheets from the stage IV help layout. There is a command for the stage IV layout. After the player waits for 3 
seconds, the image in the layout can be clicked on and the stage IV game starts.

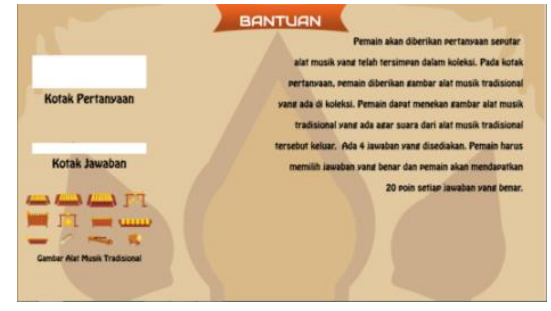

Figure 15 Stage V Help

Figure 15 is a layout for help for stage IV. There is a brief explanation of what the player must do in stage IV and the names of objects that are on the stage

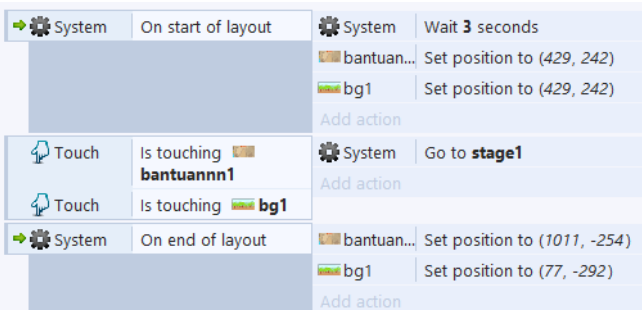

Figure 16 Stage V Help Event Sheets

Figure 16 is event sheets from the stage IV help layout. There is a command / command for the stage IV layout. After the player waits for 3 seconds, the image in the layout can be clicked on and the stage IV game starts.

\section{E. Stage I}

On stage I players play not using Joko's character. Players can only touch the brown box which will be lost when touched by the player. If the box falls into Joko's character, the stage will automatically repeat and everything returns to normal. Players must get all three treasure chest boxes containing traditional musical instruments. Display for Stage I can be seen in Figure 17.

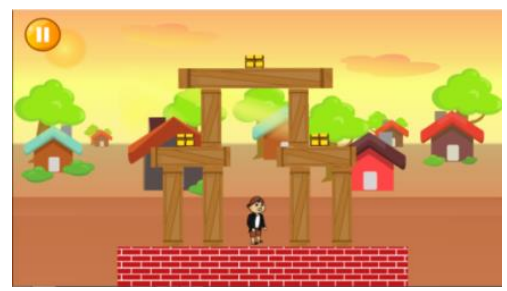

Figure 17 Layout Stage I

Figure 17 is a layout image of stage I. A rectangular object with a brown color is a box that does not reach Joko's character. The rectangular object colored with cundi and chocolate is a treasure chest that must be obtained. The button on the top left is the pause button that is used when the player is taken a short break while playing the game. When the pause button is pressed, there will be 3 options, namely further, help, exit. Advanced button to continue the game, the help button to see the procedure for playing, the exit button to return to the main menu.

\section{F. Stage II}

In stage II players play using Joko's character. Players can control Joko's character by using the up and down buttons at the bottom left of the game screen. Players must avoid holes in the road and take all the pieces of traditional musical instruments. If the character is hit by a hole, the stage will automatically repeat itself and all will return to normal, the pieces of traditional musical instruments that have been lost will disappear. Display for Stage II can be seen in Figure 18.

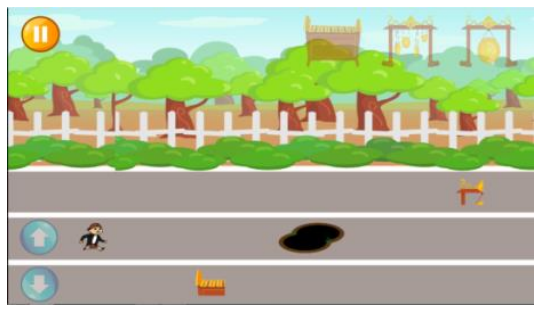

Figure 18 Layout Stage II

Figure 18 is a layout image of stage II. Black and brown objects are holes in the road that must be avoided. Gold and brown colored objects are fragments of traditional musical instruments that must be obtained. The button on the top left is the pause button that is used when the player wants to take a short break while playing the game. When the pause button is pressed, there will be 3 options, namely further, help, exit. Advanced button to continue the game, the help button to see the procedure for playing, the exit button to return to the main menu.

When the pause button is pressed, there will be 3 buttons, namely the advanced button, help, and exit. Advanced button to continue the game, the help button to see how to play at that stage, and the exit button to go to the main menu. 


\section{G. Stage III}

In stage III players play not using Joko's character. The player can only touch the key that moves towards the brown chest. If the key that does not match the lock key touches the chest, the red health bar to the right of the layout will decrease. Players get 3 times the chance, if the keys that do not match touch 3 times in a chest that has a different key, the game will return to normal (restart). Display for Stage III can be seen in Figure 19.

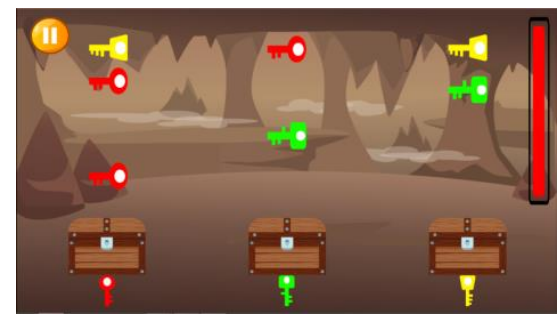

Figure 19 Layout Stage III

Figure 19 is a layout image of stage IV. A rectangular object that is brown in color is a chest that must be left to touch the same key as the key belonging to the chest. The player must touch a key that is not the same as the lock key if the health bar will not decrease and if the health bar is empty the game will return to normal. The button on the top left is the pause button that is used when the player is taken a short break while playing the game. When the pause button is pressed, there will be 3 options, namely further, help, exit. Advanced button to continue the game, the help button to see the procedure for playing, the exit button to return to the main menu.

\section{H. Stage IV}

On stage IV players play using Joko's character. Players can control the character of Joko by using the right, left, and jump buttons found in the lower left and right bottom of the game screen. Players must avoid the bullets fired by the enemy and get a treasure chest containing traditional music. When hit by a bullet, the stage will automatically repeat itself and everything returns to normal. Display for Stage IV can be seen in Figure 20.

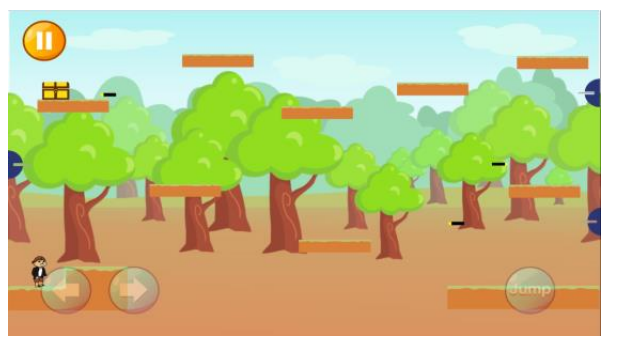

Figure 20 Layout Stage IV

Figure 20 is a layout image of stage IV. Black objects and cundi are bullets that must be avoided. The rectangular object colored with cundi and chocolate is a treasure chest that must be obtained. The button on the top left is the pause button that is used when the player is taken a short break while playing the game. When the pause button is pressed, there will be 3 options, namely further, help, exit. Advanced button to continue the game, the help button to see the procedure for playing, the exit button to return to the main menu.

\section{Stage V}

On stage $\mathrm{V}$ the player plays not using Joko's character. To be able to play stage V, players must first learn by reading and listening to the sounds of traditional musical instruments that they have gotten on stage I IV. Players are given 5 questions containing what traditional musical instruments are in the picture on the question. There are 4 answers provided and players are required to choose one. The maximum score that can be obtained is 100. If the player succeeds in selecting the correct answer then the player gets 20 points, if the answer chosen is wrong then the player does not get points. Display for Stage V can be seen in Figure 21.

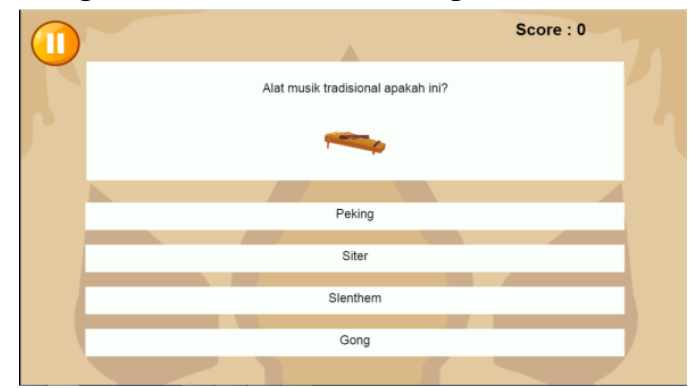

Figure 21 Layout Stage V

Figure 21 is a layout image of stage V. The large object of a white rectangle is where the question appears. 4 small rectangular objects are the answer choices 
for questions. In the question a picture of a traditional musical instrument appears which when pressed will appear the sound of the traditional musical instrument.

\section{J. Collection}

In the Collection section, players can see brief information about traditional musical instruments that have been obtained from the completed stage. It can also play what sounds from traditional musical instruments that have been obtained. Views for collections can be seen in Figures 21, 22 and 23.

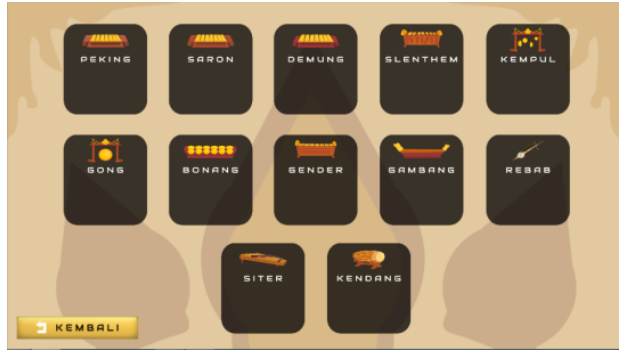

Figure 21 Collection Layout

In Figure 21 is the collection layout. When all stages have been completed, there are a total of 12 traditional musical instruments that will be in the Collection. The back button when pressed will direct the layout to the main menu.

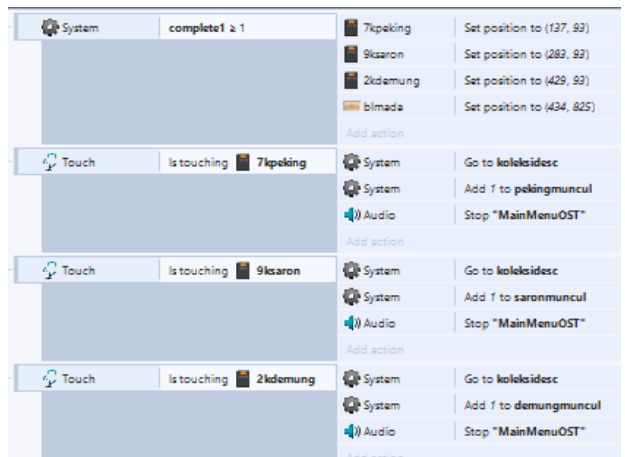

Figure 22 Collection Event Sheets Layout

In Figure 22, event sheets layout collections. If the stage has been completed, traditional musical instruments will be stored and appear in the Collection layout.

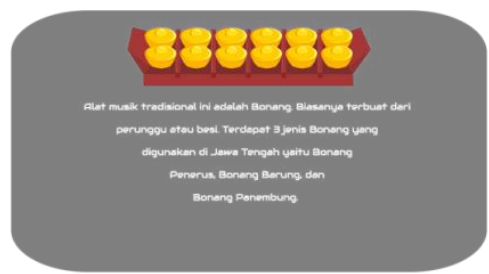

Figure 23 Collections Layouts for Traditional Musical Instruments
In Figure 23 is Layout in traditional musical instruments that are in the Collection when touched by a choice of traditional musical instruments. There is information about traditional musical instruments in the Collection. As well as players can also hear sounds like what traditional musical instruments have been obtained.

\section{K. Survey Results}

After the questionnaire was distributed to respondents, there were 41 respondents who were elementary school children. The results of the questionnaire are in the form of a diagram that can be seen in Table 1.

Table 1 Survey Results

\begin{tabular}{|c|c|c|c|c|c|}
\hline Questions & \multicolumn{5}{|c|}{ Answer } \\
\hline $\begin{array}{l}\text { How interested } \\
\text { are you with } \\
\text { traditional } \\
\text { Central } \\
\text { Javanese } \\
\text { musical } \\
\text { instruments }\end{array}$ & $\begin{array}{l}29.3 \\
\% \\
\text { chose } \\
\text { Very } \\
\text { Intere } \\
\text { sted }\end{array}$ & $\begin{array}{l}48.8 \% \\
\text { choose } \\
\text { Intereste } \\
\mathrm{d}\end{array}$ & $\begin{array}{l}17.1 \% \\
\text { choose } \\
\text { So-so }\end{array}$ & $\begin{array}{l}4.9 \% \\
\text { chose } \\
\text { Little }\end{array}$ & $\begin{array}{l}0 \% \\
\text { choose } \\
\text { Not } \\
\text { Intereste } \\
\mathrm{d}\end{array}$ \\
\hline $\begin{array}{l}\text { How often do } \\
\text { you play games }\end{array}$ & $\begin{array}{l}19.5 \\
\% \\
\text { who } \\
\text { choos } \\
\text { e } \\
\text { Very } \\
\text { Often } \\
\end{array}$ & $\begin{array}{l}34.1 \% \\
\text { who } \\
\text { choose } \\
\text { Often }\end{array}$ & $\begin{array}{l}29.3 \% \\
\text { who } \\
\text { chose } \\
\text { Sufficie } \\
\text { nt }\end{array}$ & $\begin{array}{l}14.6 \% \\
\text { who } \\
\text { chose } \\
\text { Rarely }\end{array}$ & $\begin{array}{l}2.4 \% \\
\text { who } \\
\text { chose } \\
\text { Very } \\
\text { Rarely }\end{array}$ \\
\hline $\begin{array}{l}\text { Is there an } \\
\text { impact felt } \\
\text { after playing } \\
\text { the game Joko } \\
\text { Sinau }\end{array}$ & $\begin{array}{l}17.1 \\
\% \\
\text { who } \\
\text { choos } \\
\text { e } \\
\text { Plent } \\
\text { y }\end{array}$ & $\begin{array}{l}43.9 \% \\
\text { who } \\
\text { chose } \\
\text { There Is }\end{array}$ & $\begin{array}{l}17.1 \% \\
\text { who } \\
\text { choose } \\
\text { So-so }\end{array}$ & $\begin{array}{l}9.8 \% \\
\text { who } \\
\text { chose } \\
\text { Little }\end{array}$ & $\begin{array}{l}12.2 \% \\
\text { who } \\
\text { chose } \\
\text { None }\end{array}$ \\
\hline $\begin{array}{l}\text { What effect do } \\
\text { you feel after } \\
\text { playing Joko } \\
\text { Sinau }\end{array}$ & $\begin{array}{l}0 \% \\
\text { who } \\
\text { chose } \\
\text { None }\end{array}$ & $\begin{array}{l}26.8 \% \\
\text { who } \\
\text { chose } \\
\text { All of } \\
\text { The } \\
\text { Options }\end{array}$ & $\begin{array}{l}29.3 \% \\
\text { who } \\
\text { choose } \\
\text { Want to } \\
\text { Play } \\
\text { Again }\end{array}$ & $\begin{array}{l}12.2 \% \\
\text { who } \\
\text { chose } \\
\text { Pleased }\end{array}$ & $\begin{array}{l}31.7 \% \\
\text { who } \\
\text { choose } \\
\text { Increasi } \\
\text { ng } \\
\text { Knowle } \\
\text { dge }\end{array}$ \\
\hline $\begin{array}{l}\text { Is there new } \\
\text { knowledge } \\
\text { gained after } \\
\text { playing Joko } \\
\text { Sinau }\end{array}$ & $\begin{array}{l}22 \% \\
\text { who } \\
\text { choos } \\
\text { e } \\
\text { Plent } \\
\text { y }\end{array}$ & $\begin{array}{l}68.3 \% \\
\text { who } \\
\text { chose } \\
\text { There Is }\end{array}$ & $\begin{array}{l}7.3 \% \\
\text { who } \\
\text { choose } \\
\text { So-so }\end{array}$ & $\begin{array}{l}2.4 \% \\
\text { who } \\
\text { chose } \\
\text { Little }\end{array}$ & $\begin{array}{l}0 \% \text { who } \\
\text { choose } \\
\text { None }\end{array}$ \\
\hline $\begin{array}{l}\text { Are you } \\
\text { interested in } \\
\text { the Joko Sinau } \\
\text { game }\end{array}$ & $\begin{array}{l}51.2 \\
\% \\
\text { who } \\
\text { chose } \\
\text { Very } \\
\text { Intere } \\
\text { sted }\end{array}$ & $\begin{array}{l}36.6 \% \\
\text { who } \\
\text { chose } \\
\text { Intereste } \\
\text { d }\end{array}$ & $\begin{array}{l}4.9 \% \\
\text { who } \\
\text { choose } \\
\text { So-so }\end{array}$ & $\begin{array}{l}7.3 \% \\
\text { who } \\
\text { chose } \\
\text { Little }\end{array}$ & $\begin{array}{l}0 \% \text { who } \\
\text { choose } \\
\text { No }\end{array}$ \\
\hline $\begin{array}{l}\text { Does the Joko } \\
\text { Sinau game } \\
\text { help give you } \\
\text { knowledge } \\
\text { about } \\
\text { traditional } \\
\text { Central } \\
\text { Javanese } \\
\text { musical } \\
\text { instruments }\end{array}$ & $\begin{array}{l}34.1 \\
\% \\
\text { who } \\
\text { choos } \\
\text { e } \\
\text { Very } \\
\text { Helpf } \\
\text { ul }\end{array}$ & $\begin{array}{l}61 \% \\
\text { who } \\
\text { chose } \\
\text { Helpful }\end{array}$ & $\begin{array}{l}2.4 \% \\
\text { who } \\
\text { choose } \\
\text { So-so }\end{array}$ & $\begin{array}{l}2.4 \% \\
\text { who } \\
\text { chose } \\
\text { Little }\end{array}$ & $\begin{array}{l}0 \% \text { who } \\
\text { choose } \\
\text { No }\end{array}$ \\
\hline $\begin{array}{l}\text { Is there a desire } \\
\text { to play Joko } \\
\text { Sinau again }\end{array}$ & $\begin{array}{l}63,4 \\
\% \\
\text { who } \\
\text { choos } \\
\text { e } \\
\text { Eager } \\
\text { to }\end{array}$ & $\begin{array}{l}29.3 \% \\
\text { who } \\
\text { chose } \\
\text { There Is }\end{array}$ & $\begin{array}{l}4.9 \% \\
\text { who } \\
\text { choose } \\
\text { So-so }\end{array}$ & $\begin{array}{l}2.4 \% \\
\text { who } \\
\text { chose } \\
\text { Little }\end{array}$ & $\begin{array}{l}0 \% \text { who } \\
\text { choose } \\
\text { No }\end{array}$ \\
\hline
\end{tabular}




\begin{tabular}{|c|c|c|c|c|c|}
\hline $\begin{array}{l}\text { The difficulty } \\
\text { level in playing } \\
\text { Joko Sinau }\end{array}$ & $\begin{array}{l}2.4 \% \\
\text { who } \\
\text { choos } \\
\text { e } \\
\text { Very } \\
\text { Diffic } \\
\text { ult }\end{array}$ & $\begin{array}{l}19.5 \% \\
\text { who } \\
\text { chose } \\
\text { Difficult }\end{array}$ & $\begin{array}{l}41.5 \% \\
\text { who } \\
\text { choose } \\
\text { So-so }\end{array}$ & $\begin{array}{l}19.5 \% \\
\text { who } \\
\text { choose } \\
\text { Easy }\end{array}$ & $\begin{array}{l}17.1 \% \\
\text { who } \\
\text { chose } \\
\text { Very } \\
\text { Easy }\end{array}$ \\
\hline $\begin{array}{l}\text { What needs to } \\
\text { be improved in } \\
\text { the Joko Sinau } \\
\text { game }\end{array}$ & $\begin{array}{l}34.1 \\
\% \\
\text { who } \\
\text { chose } \\
\text { None } \\
\end{array}$ & $\begin{array}{l}29.3 \% \\
\text { who } \\
\text { chose } \\
\text { Everythi } \\
\text { ng }\end{array}$ & $\begin{array}{l}2.4 \% \\
\text { who } \\
\text { chooses } \\
\text { Sound }\end{array}$ & $\begin{array}{l}14.6 \% \\
\text { who } \\
\text { chose } \\
\text { Gamepl } \\
\text { ay }\end{array}$ & $\begin{array}{l}19.5 \% \\
\text { Who } \\
\text { chooses } \\
\text { Graphic } \\
\text { s }\end{array}$ \\
\hline
\end{tabular}

Table 1 revealed the respon of respondents regard to they play the Joko Sinau Game. The table showed: $48.8 \%$ respondents interested in traditional music instrument; $43.9 \%$ respondents feel there is an impact felt after playing game Joko Sinau; $31.7 \%$ respondents feel their knowledge increased after playing game Joko Sinau; $68.3 \%$ respondents feel they gained knowledge after playing game Joko Sinau; $51.2 \%$ respondents very interested in playing game Joko Sinau; 61\% respondents thinks game Joko Sinau helpful for them to know more about traditional instrument in Central Java; $63.4 \%$ respondents eager to play game Joko Sinau again; $41.5 \%$ respondents felt soso about the difficulty level in playing Joko Sinau; and $34.1 \%$ respondents felt none to be improved in Joko Sinau.

\section{CONCLUSION}

From the results of the questionnaire described above, it can be concluded that elementary school children have an interest in traditional musical instruments. Children also like to play games, so if there are games that contain knowledge about traditional musical instruments they are very enthusiastic to play it. Apart from getting their knowledge they also get their own pleasure by playing games. Children feel the game "Joko Sinau: Traditional Music in Central Java" has a positive impact on them. They also considered that this game helped provide knowledge about traditional musical instruments in Central Java. There is a desire from children to play this game again and they hope there will be an increase in graphics, gameplay, and sound in the game.

\section{REFERENCES}

[1] B. Seni, B. Berkonteks, K. Hidup, D.

A. N. Menyenangkan, B. Siswa, and S.
D. Mi, "Pengembangan materi pembelajaran seni musik berbasis seni budaya berkonteks kreatif, kecakapan hidup, dan menyenangkan bagi siswa sd/mi."

[2] A. R. Patji, "P ENGEMBANGAN DAN P ERLINDUNGAN K EKAYAAN B UDAYA D AERAH : R ESPON P EMERINTAH I NDONESIA T ERHADAP," pp. 167188, 2010.

[3] Kompas.com, "Anak Muda Ogah Melirik Seni Tradisional", 14/09/2008, 2008. [Online]. Available:

https://nasional.kompas.com/read/2008 /09/14/02422737/anak.muda.ogah.meli rik.seni.tradisional, [Accessed: 24-Okt2018]

[4] Kompasiana.com, "Kurangnya Minat Generasi Muda Terhadap Musik Tradisional", 01/01/2017, 2017. [Online]. Available:

https://www.kompasiana.com/mangsan ip/5869297f1fafbdfb1fa08788/kurangn ya-minat-generasi-muda-terhadapmusik-tradisional, [Accessed: 24-Okt2018]

[5] Kurniawati Atik, "Menghidupkan Musik Gamelan di Kalangan Remaja", 20/08/2018, 2018. [Online]. Available: https://muda.kompas.id/2018/08/20/me nghidupkan-musik-gamelan-dikalangan-remaja, [Accessed: 24-Okt2018]

[6] B. Zaman, M. Pd, and H. C. Eliyawati, "Media Pembelajaran Anak Usia Dini," Media Pembelajaran Anak Usia Dini, p. 34, 2010.

[7] L. J. Moleong, "Metode Penelitian," pp. 1-12, 2004. 